Огляди літератури, оригінальні дослідження, погляд на проблему, випадок з практики, короткі повідомлення УдК 616.125-008.313.2-02:616.12-008.331.1-06:616.379-008.64

DOI 10.11603/1811-2471.2021.v.i2.12054

\title{
КЛІНІЧНИЙ ПОРТРЕТ ПАЦІЄНТІВ ІЗ ФІБРИЛЯЦІЄЮ ПЕРЕДСЕРДЬ: ДАНІ ВЛАСНИХ СПОСТЕРЕЖЕНЬ У КОГОРТІ ХВОРИХ ІЗ КОМОРБІДНИМИ АРТЕРІАЛЬНОЮ ГІПЕРТЕНЗІЕЮ ТА ЦУКРОВИМ ДІАБЕТОМ 2-ГО ТИПУ
}

\author{
๑М. В. Гребеник, Ю. В. Гончарук
}

Тернопільський національний медичний університет імені І. Я. Горбачевського МОЗ України

Вступ. Фібриляція передсердь (ФП) є найбільш розповсюдженим порушенням ритму і наявна у 1-2 \% осіб у світі. Передбачається, що до 2060 р. кількість осіб з ФП досягне 17,9 млн. Фремінгемське епідеміологічне дослідження показало, що АГ та ЦД $є$ незалежними предикторами виникнення ФП. Тому попередження виникнення, прогнозування перебігу даної аритмії в осіб з вказаною супутньою патологією набуває особливої актуальності.

Мета - провести клініко-функціональне зіставлення розвитку та перебігу ФП в умовах коморбідних АГ і ЦД.

Матеріал і методи. Обстежено 186 пацієнтів віком від 20 до 74 років, в тому числі 55,9\% чоловіків і 44,1 \% жінок. ФП виявлена у 80,1 \% хворих (основна група), не виявлено порушень ритму у 13,4 \% (контрольна група).

Результат. При обстеженні хворих із ФП виявлено такий розподіл за статтю: чоловіків було 61,7 \%, жінок 38,3 \%, причому чоловіки виявились в середньому на 4 роки молодшими.

Виявлено, що таке ускладнення гіпертензивного серця як ФП найчастіше виникає через 10 років після виявлення АГ. При розвитку ЦД ФП виникає швидше, ніж при ізольованій АГ. Чим тривалішим був анамнез АГ і ЦД, тим більше хворих мали ФП.

Клінічно хворі з АГ та ЦД часто не відчували рецидиву пароксизмів аритмії, що, ймовірно, вплинуло на прогресування патології.

Виявилось, що тривале вживання алкоголю безпосередньо впливає на зміни показників ЕхоКГі, як наслідок, на виникнення пароксизмів ФП. Поєднання АГ та ЦД також має вагомий вплив на ремоделювання серця та персистенцію ФП, а виражена ГЛШ у групі хворих із СР і АГ, ймовірно, пов'язана з гіршим медикаментозним контролем АГ.

Висновок. ФП у хворих з АГ і ЦД 2-го типу характеризується менш яскравою клінічною симптоматикою, прихованим початком, прогресуванням ремоделювання серця, схильністю до трансформації у постійну форму та гіршим прогнозом.

КЛючОВІ СлОВА: фібриляція передсердь; артеріальна гіпертензія; цукровий діабет.

Вступ. На сьогодні фібриляція передсердь (ФП) $є$ найпоширенішним порушенням ритму, яке виявляють у 1-2 \% осіб у світі. В Європі від цього порушення страждають понад 6 мільйонів людей. Припускають, що до 2060 р. в Європейському Союзі кількість осіб із ФП у віці понад 55 років досягне 17,9 млн. [1] Проте статистичні дані щодо поширення ФП досить обмежені, адже пароксизм ФП виникає гостро лише у 25 \% випадків і вперше діагностується лікарями екстреної або невідкладної медичної допомоги. У 75 \% випадків ФП виявляють зазвичай випадково, під час профілактичних оглядів або при зверненні з приводу інших захворювань. [5]

Часто власне коморбідна патологія сприяє виникненню і персистуванню ФП. Фремінгемське епідеміологічне дослідження показало, що наявність таких захворювань як артеріальна гіпертензія (АГ) та цукровий діабет (ЦД) $є$ незалежними предикторами виникнення ФП. Тому запобігання виникненню, прогнозування перебігу цієї аритмії в осіб із вказаною супутньою патологією набуває особливої актуальності [6].

Щодо причин виникнення і персистенції ФП, то АГ займає перше місце (близько $72 \%$ хворих із ФП страждають АГ). ЦД 2-го типу як незалежний фактор ризику розвитку ФП науковці почали розглядати лише в останні роки. Доведено, що наявність ЦД 2-го типу збільшує ризик розвитку ФП в 1,4-2,1 раза, натомість ЦД виявляють у 10-25\% пацієнтів з попередньо діагностованою ФП [7].

Розвиток і перебіг ФП залежать від різних чинників і коморбідних станів i, зважаючи на неоднозначні результати багатьох досліджень, проблема ФП залишається актуальною й вимагає подальших досліджень.

Мета даного фрагменту нашого дослідження - провести клініко-функціональне зіставлення розвитку та перебігу ФП за наявності коморбідних АГ і ЦД.

Матеріал і методи дослідження. Дослідження проводилось на базі міського кардіоцентру. В роботі оцінювали клінічні, лабораторні та інструментальні дані. Діагноз ФП встановлювали на підставі документально зареєстрованих епізодів цієї аритмії за даними електрокардіографії (ЕКГ) або холтерівського моніторування ЕКГ (ХМ ЕКГ) з урахуванням рекомендацій EHRA (2018) (табл. 1).

Обстежено 186 пацієнтів, які зверталися в клініку з приводу порушень ритму, підвищення АТ віком від 20 до 74 років (середній вік $(59,2 \pm 0,8)$ років). Серед них було 104 (55,9 \%) чоловіки і 82 
Огляди літератури, оригінальні дослідження, погляд на проблему, випадок з практики, короткі повідомлення Таблиця 1. Клініко-функціональні показники пацієнтів обстежених груп

\begin{tabular}{|c|c|c|c|c|c|}
\hline Показник & $\begin{array}{c}\text { Ідіопатична } \\
\text { ФП (1) } \\
\end{array}$ & $\Phi П+А Г(2)$ & ФП+АГ+ЦД (3) & $C P+A \Gamma(4)$ & СР+АГ+ЦД( 5) \\
\hline \multicolumn{6}{|c|}{ Клінічні показники } \\
\hline Вік, років & $53,8 \pm 3,0(2,3)$ & $61,28 \pm 0,8(1)$ & $63,02 \pm 1,0(1,2)$ & $60,6 \pm 2,8(5)$ & $57,6 \pm 1,5(4)$ \\
\hline Індекс Кетле, кг/м² & $26,7 \pm 0,7(2,3,4,5)$ & $29,5 \pm 0,4(1)$ & $32,4 \pm 1,1(1,2)$ & $32,1 \pm 3,3(1,2)$ & $30 \pm 1,2(1)$ \\
\hline $\begin{array}{l}\text { Куріння, } \\
\text { пачкороки }\end{array}$ & $17,7 \pm 3,7$ & $26 \pm 2,9$ & $21,7 \pm 8,1$ & & \\
\hline$\Gamma \mathrm{\Gamma}$, років & & $11,1 \pm 0,7(3)$ & $18,2 \pm 1,5(2,4)$ & $11,6 \pm 2,8(3)$ & $15,8 \pm 1,5$ \\
\hline $\begin{array}{l}\text { Тривалість } \\
\text { анамнезу ФП, днів }\end{array}$ & $56,8 \pm 6,1(2,3)$ & $130,24 \pm 8,5(1,3)$ & $798,9 \pm 20,5(1,2)$ & & \\
\hline \multicolumn{6}{|c|}{ Лабораторні показники } \\
\hline Глюкоза & $5,6 \pm 0,4(2,3)$ & $6,0 \pm 0,1(1,3)$ & $8,8 \pm 0,6(1,2)$ & $5,7 \pm 0,3(5)$ & $10,0 \pm 0,9(4)$ \\
\hline Білірубін & $22,5 \pm 7,2(2,3)$ & $14,1 \pm 1,3(1)$ & $12,7 \pm 1,1(1)$ & $9,8 \pm 1,5$ & $9,6 \pm 1,1$ \\
\hline ACT & $126,1 \pm 88,9(2,3)$ & $25 \pm 1,2(1)$ & $28,3 \pm 2,0(1)$ & $22,9 \pm 4,2$ & $25 \pm 2,4$ \\
\hline АЛТ & $99,2 \pm 58,8(2,3)$ & $27,5 \pm 1,9(1)$ & $30,7 \pm 3,0(1)$ & $21,7 \pm 3,9$ & $32,5 \pm 4,4(4)$ \\
\hline Глікований Нb & $5,7 \pm 0,4$ & $5,7+0,1(3)$ & $7,5 \pm 0,3(2)$ & $5,4 \pm 0,2$ & $7,3 \pm 0,3(4)$ \\
\hline \multicolumn{6}{|c|}{ Показники ЕхоКГ } \\
\hline ЛП & $4,5 \pm 0,1(2,3,4,5)$ & $4,3 \pm 0,06(3)$ & $4,3 \pm 0,1(2)$ & $4,0 \pm 0,2$ & $4,1 \pm 0,1$ \\
\hline КДРЛШ & $5,5 \pm 0,2$ & $5,2 \pm 0,06$ & $5,5 \pm 0,1$ & $4,9 \pm 0,3$ & $5,0 \pm 0,1$ \\
\hline МШП & $0,98 \pm 0,05(2,3)$ & $1,22 \pm 0,01(1)$ & $1,28 \pm 0,03(1,2)$ & $1,34 \pm 0,07$ & $1,44 \pm 0,04(4)$ \\
\hline ЗСлш & $0,98 \pm 0,05(2,3)$ & $1,17 \pm 0,01(1)$ & $1,23 \pm 0,02(1,2)$ & $1,32 \pm 0,07$ & $1,37 \pm 0,03(4)$ \\
\hline ФB & $47,5 \pm 4,1$ & $52,1 \pm 1,0(3)$ & $47,3 \pm 2,0$ & $57,4 \pm 2,6(1,3)$ & $57,6 \pm 1,6(1,3)$ \\
\hline ПШВ & $0,82 \pm 0,02(3)$ & $0,82 \pm 0,009(3)$ & $0,86 \pm 0,01(1,2,4,5)$ & $0,83 \pm 0,05(3)$ & $0,81 \pm 0,02(3)$ \\
\hline BTC & $0,37 \pm 0,03(2,3,4,5)$ & $0,46 \pm 0,008(1,4,5)$ & $0,47 \pm 0,01(1,4,5)$ & $0,55 \pm 0,04(1,2,3)$ & $0,55 \pm 0,01(1,2,3)$ \\
\hline \multicolumn{6}{|c|}{ Індекси коморбідності } \\
\hline $\begin{array}{l}\text { Чарлсон } \\
\text { (\% виживання) }\end{array}$ & $82,3 \pm 5,3(2,3)$ & $74,1 \pm 2,0(1,3)$ & $41,9 \pm 3,0(1,2)$ & $76 \pm 6,7$ & $67 \pm 5,3(4)$ \\
\hline CIRS & $8,9 \pm 0,7(2,3)$ & $10,6 \pm 0,4(1,3)$ & $14,3 \pm 0,6(1,2)$ & $10,5 \pm 0,8$ & $14,6 \pm 1,0(1,2,4)$ \\
\hline Procam Weibull & $10,9 \pm 3,0$ & $11,6 \pm 0,9(3)$ & $17,3 \pm 1,5(2)$ & $16 \pm 5,3$ & $18,4 \pm 3,5(1,2,4)$ \\
\hline
\end{tabular}

Примітка: в дужках вказана достовірна відмінність $(\mathrm{p}<0,05)$ між групами 1-5.

$(44,1 \%)$ жінки. В процесі дообстеження ФП верифіковано у 149 (80,1 \%) хворих (основна група), серед них ідіопатична ФП (n=15), ФП в поєднанні з АГ $(n=93)$ та ФП з коморбідними АГ та ЦД 2-го типу $(n=41)$. Інші порушення ритму діагностовано у 12 хворих (6,5\%), не виявлено порушень ритму у 25 (13,4 \%) обстежених (контрольна група).

у 45 (30,2 \%) пацієнтів діагностована пароксизмальна форма ФП, у 74 (49,6 \%) - персистентна, у 30 (20,2 \%) - постійна.

Критеріями виключення стали вік пацієнта понад 75 років та наявність ФП клапанної етіології.

Статистичну обробку отриманих даних проводили з використанням програми SPSS 21.0. Усі результати представлені із зазначенням середньої помилки $(\mathrm{M} \pm \mathrm{m})$. Достовірність відмінностей між кількісними ознаками визначали за критері$\epsilon м \mathrm{~L}$ Стьюдента $(p<0,05)$, а за якісними ознаками за $\chi^{2}$ Фішера $(p<0,05)$.

Результати й обговорення. Багато досліджень вказують на те, що чоловіки частіше страждають на цю патологію, ніж жінки. При обстеженні хворих із ФП ми виявили такий розподіл за статтю: чоловіків було 61,7 \%, жінок - 38,3 \%. Причому середній вік чоловіків у цій групі становив 59,5 років, тоді як жінок - 63,5 роки, тобто ФП у жінок зустрічається рідше і у більш пізньому віці $(p=0,004)$.

Відомо, що вік суттєво пов'язаний із частотою виявлення ФП. За нашими даними, найстарші пацієнти були в групі ФП з АГ і ЦД-в середньому 63 роки, проти групи ідіопатичної ФП, де середній вік становив 53,8 року $(p=0,0004)$.

Тривалість аритмічного анамнезу в когорті обстежених нами хворих визначалась з моменту першого зареєстрованого епізоду ФП та становила від 1 місяця до 30 років (в середньому $(4,5 \pm 0,6)$ року). Кількість епізодів ФП за останній рік коливалась від 1 до 30 пароксизмів (у середньому $5,3 \pm 0,8)$.

Коморбідність також вносить корективи у вікову структуру хворих із ФП. Аналіз коморбідної патології виявив таке: у дослідженні переважали пацієнти з ІІ стадією гіпертонічної хвороби (ГХ) $75 \%$, тоді як з ІІІ стадією - $20 \%$, і з I - лише 5 \%. 
Огляди літератури, оригінальні дослідження, погляд на проблему, випадок з практики, короткі повідомлення

Анамнез АГ коливався від 1 до 40 років (в середньому становив $(13,5 \pm 0,7)$ років). При цьому найбільше пацієнтів було з тривалістю анамнезу АГ 10-20 р. - 56,4 \%, з тривалістю до 10 р. - 28,8\%, i найменше - з тривалістю більше 20 р. - 14,8 \%. Тобто, таке ускладнення гіпертензивного серця як ФП найчастіше виникає через 10 років після виявлення АГ.

Анамнез ЦД 2-го типу коливався від 1 до 15 років і в середньому становив $(5,0 \pm 0,4)$ року. При розвитку ЦД ФП у пацієнтів виникає швидше, порівняно з ізольованою АГ.

Тривалість анамнезу АГ і ЦД теж впливає на розвиток ФП. ГХ найдовше тривала в групі ФП з АГ і ЦД - в середньому 18,2 року, проти груп ізольованої АГ з ФП та з синусовим ритмом (СР) $11,1$ року ( $p=0,00009)$. Чим тривалішим був анамнез коморбідних АГ і ЦД, тим більша частка хворих мала ФП.

У дослідженнях пацієнтів з АГ та ЦД 2-го типу незалежним предиктором розвитку рецидивів ФП $\epsilon$ індекс маси тіла (IMT). При його збільшенні на одну одиницю ризик розвитку рецидивів ФП значно зростає [6].

Індекс Кетле у нашому дослідженні виявився найвищим у групі ФП з коморбідними АГ і ЦД $32,4 \pm 1,2$, тоді як у групі ідіопатичної ФП він становив $26,7 \pm 0,7$ ( $p=0,01)$. Це, можливо, було одним із чинників трансформації пароксизмальноїта персистентої ФП у перманентну в коморбідних хворих.

Середня тривалість анамнезу ФП в обстежених нами хворих також виявилась набагато вищою в групі ФП, АГ і ЦД - 798,9 дня, тоді як у групі ФП і АГ - 130,2 дня ( $p=0,002)$, а в групі ідіопатичної ФП - лише 56,8 дня ( $p=0,002)$. Клінічно хворі з АГ та ЦД часто не відчували рецидиву пароксизмів аритмії, що, ймовірно, вплинуло на прогресування патології і розвитку її постійної форми.

Слід зазначити, що за даними досліджень низки науковців, у хворих на ГХ з ЦД 2-го типу часто спостерігаються безсимптомні порушення ритму, що вказує на доцільність включення добового профілю ЕКГ у клінічне дослідження таких пацієнтів для своєчасного виявлення аритмій [8].

Ми також отримали дані, згідно з якими постійна форма ФП найчастіше спостерігалася в групі з АГ і ЦД. Якщо не брати до уваги постійну форму ФП, то середня тривалість епізоду в групі пароксизмальної ФП становила $(4,4 \pm 1,2)$ днів, в групі персистентої форми ФП - $(11,6 \pm 2,0)$ днів. У групі ідіопатичної ФП середня тривалість епізоду була $(7,7 \pm 1,7)$ днів, в групі ФП та АГ - $(18,0 \pm 3,9)$ днів, а в групі ФП, АГ та ЦД - $(13,1 \pm 4,7)$ днів.

На тлі зростання знань про етіологію і механізми виникнення ФП з'являються питання щодо того, чи існує ця аритмія ізольовано? Якщо в 1954 році в структурі ФП розглядали ізольовану або ідіопатичну ФП у 30 \% осіб, то у 2014 р. - лише у 3 \%, а $27 \%$ віднесено до «нових форм» захворювання (каналопатії, фіброз передсердь, діастолічна дисфункція тощо) [4]. У великій кількості досліджень доведено, що в багатьох пацієнтів, у яких при госпіталізації діагностували ФП без супутніх захворювань, згодом виявляли коморбідну патологію. Через це вчені все більше уваги приділяють вивченню факторів ризику, що сприяють розвитку ФП [3].

В обстежених нами пацієнтів у групі ідіопатичної ФП спостерігалось значне порушення показників функціонального стану печінки. У вказаній когорті хворих інцидент ФП, як правило, збігався з алкогольним ексцесом. Пацієнти з ФП, які хронічно вживали алкоголь, мали в 3-4 рази вищі показники білірубіну, АСТ, АлТ, ніж ті, які алкоголю не вживали ( $p=0,00001)$. Тобто вживання алкоголю в когорті обстежених нами хворих виявилось провідним фактором ризику виникнення пароксизму ФП у групі ідіопатичної ФП.

Глюкоза та глікований Нb закономірно були найвищими в групах з ЦД ( $p=0,00004)$.

Персистенція ФП призводить до прогресування електрофізіологічного, скоротливого і структурного ремоделювання передсердь, що лежить в основі феномену «ФП породжує ФП» [2].

Зовсім несподіваними виявились зміни ехокардіографічних (ЕхоКГ) проказників у когорті обстежених пацієнтів з ідіопатичною ФП. Згідно 3 показниками ЕхоКГ ми отримали такі дані: ліве передсердя мало найбільші розміри у групі ідіопатичної ФП ( $=0,002)$. Кінцево-систолічний розмір лівого шлуночка був найбільшим у групах ідіопатичної ФП та ФП в поєднанні з АГ і ЦД ( $p=0,037)$. Фракція викиду була найменшою в групах ідіопатичної ФП та ФП, АГ і ЦД $(p=0,03)$. Тому тривале вживання алкоголю має безпосередній вплив на зміни показників ЕхоКГ (у групі ідіопатичної ФП) і, як наслідок, на виникнення пароксизмів ФП. Ми виявили, що поєднання АГ та ЦД також має вагомий вплив на ремоделювання серця та персистенцію ФП.

3 іншого боку, виражена ГЛШ у групі хворих із СР і АГ, ймовірно, пов'язана з гіршим медикаментозним контролем АГ, порівняно з коморбідними хворими. Міжшлуночкова перегородка та задня стінка лівого шлуночка були найбільш гіпертрофованими в групах СР з АГ та з АГ і ЦД (p=0,007).

Згідно з даними ретроспективного аналізу анамнезу, клінічної симптоматики, змін функціонального стану, за лабораторними показниками, морфофункціональними характеристиками міокарда та за даними ЕхоКГ можна зробити висновок, що такі зміни на тлі ідіопатичної ФП є наслідком розвитку алкогольної кардіоміопатії. 
Огляди літератури, оригінальні дослідження, погляд на проблему, випадок з практики, короткі повідомлення

Згідно з індексом коморбідності Чарлсона, показник виживання пацієнтів закономірно був найвищим у групі з ідіопатичною ФП, тоді як найнижчим - в групі ФП, АГ і ЦД ( $p=0,0001)$.

Глибина ураження інших органів і систем була найвищою в групах із АГ та ЦД, незалежно від наявності чи відсутності ФП ( $p=0,0001)$.

10-річний ризик гострих коронарних подій згідно з системою Рrocam Weibull також був найвищим у групах з АГ і ЦД та з ФП чи СР (p=0,001). Тобто поєднання таких захворювань як АГ і ЦД суттє- во впливає як на виникнення та персистування ФП, так і на появу гострих коронарних подій.

Висновок. ФП у коморбідних хворих з АГ і ЦД 2-го типу характеризується менш яскравою клінічною симптоматикою, прихованим початком, прогресуванням ремоделювання серця, схильністю до трансформації у постійну форму та гіршим прогнозом.

Перспективи подальших досліджень. Низка виявлених нез'ясованих і суперечливих даних вимагає проведення додаткових досліджень.

\section{ЛІТЕРАТУРА}

1. Projections on the number of individuals with atrial fibrillation in the European Union, from 2000 to 2060 / B. P. Krijthe, A. Kunst, E. J. Benjamin [et al.] // Europen Heart Journal. - 2013. - Vol. 34 (35). - P. 2746-2751.

2. Nattel S. Atrial remodeling and atrial fibrillation: recent advances and translational perspectives / S. Nattel, M. Harada // Journal of the American College of Cardiology. - 2014. - Vol. 63 (22). - P. 2335-2345.

3. Risk Factor Management in Atrial Fibrillation / A. Brandes, M. D. Smit, B. O. Nguyen [et al.] // Arrhythmia \& Electrophysiology Review. - 2018. - Vol. 7 (2). P. $118-127$.

4. Lone atrial fibrillation: does it exist? / D. G. Wyse, I. V. Gelder, P. Ellinor [et al.] // Journal of the American College of Cardiology. - 2014. - Vol. 63 (17). - Р. 1715-1723.

5. Бова А.А. Фибрилляция предсердий в практике терапевта / А. А. Бова // Военная медицина. - 2018. № 1 (46). - C. 6-10.

6. Ковбаснюк Ю. В. Аналіз факторів ризику розвитку ускладнень при фібриляції передсердь та визначення подальшої тактики антикоагулянтної терапії / Ю. В. Ковбаснюк, Н. В. Горач // Ліки України. - 2015. № 3 (24). - С. 74-79.

7. Артериальная гипертензия, сахарный диабет 2 типа и фибрилляция предсердий как самостоятельная медицинская проблема / А. В. Барсуков, Т. С. Свеклина, М. С. Таланцева, С. Б. Шустов // Артериальная гипертензия. - 2011. - Т. 17, № 2. - С. 108-114.

8. Формування порушення ритму серця у хворих на артеріальну гіпертензію з цукровим діабетом 2 типу / Т. Г. Старченко, С. М. Коваль, К. О. Юшко [та ін.] // Вісник проблем біології і медицини. - 2018. - Вип. 3. - С. 42-46.

\section{REFERENCES}

1. Krijthe, B.P., Kunst, A., Benjamin, E.J., Lip, G.Y., Franco, O.H., Hofman, A., \& Heeringa, J. (2013). Projections on the number of individuals with atrial fibrillation in the European Union, from 2000 to 2060. Europen Heart Journal, 34, 2746-51. http://doi:10.1093/eurheartj/eht280

2. Nattel, S., \& Harada, M. (2014). Atrial remodeling and atrial fibrillation: recent advances and translational perspectives. Journal of the American College of Cardiology, 63 (22), 2335-2345. http://doi:10.1016/j.jacc.2014.02.555

3. Brandes, A., Smit, M.D., Nguyen, B.O., Rienstra, M., \& Gelder, I.V. (2018). Risk Factor Management in Atrial Fibrillation. Arrhythmia \& Electrophysiology Review, 7 (2), 118-127. http://doi: 10.15420/aer.2018.18.2

4. Wyse, D., Gelder, V.I., Ellinor, P., Alan, S.Go, Kalmanet, J.M., Narayan, S.M., \& Rienstra, M. (2014). Lone atrial fibrillation: does it exist? Journal of the American College of Cardiology, 63 (17), 1715-1723. http://doi.org/10.1016/j. jacc.2014.01.023

5. Bova, A.A. (2018). Fibriliatsiia priedsierdiy v praktikie tieratievta [Atrial fibrillation in the practice of a therapist]. Voiennaia mieditsyna - Military Medicine, 1 (46), 6-10 [in Russian].

6. Kovbasnyuk, Yu.V., \& Gorach, N.V. (2015). Analiz faktoriv ryzyku rozvytku uskladnen pry fibryliatsii peredserd ta vyznachennia podalshoyi taktyky antykoahuliantnoyi terapiyi [Analysis of risk factors for complications of atrial fibrillation and determination of further tactics of anticoagulant therapy]. Liky Ukrainy-Medicines of Ukraine, 3 (24), 74-79. [in Ukrainian].

7. Barsukov, A.V., Sveklyna, T.S., Talanceva, M.S., \& Shustov, S.B. (2011). Arterialnaia hipertienziya, sakharnyi diabet 2 tipa I fibriliatsia predserdiy kak samostoiatelnaya mieditsynskaya probliema [Arterial hypertension, type 2 diabetes mellitus and atrial fibrillation as an independent medical problem]. Arterialnaia hipertenziya - Arterial hypertension, 7 (2), 108-114. [in Russian].

8. Starchenko, T.G., Koval, S.M., Yushko, K.O., Shkapo, V.L., \& Myloslavskyi, D.K. (2018). Formuvannia porushennia rytmu sertsia u khvoryh na arterialnu hipertenziyu $z$ tsukrovym diabetom 2 typu [Formation of cardiac arrhythmia in patients with hypertension with type 2 diabetes]. Visnyk problem biolohii i medytsyny - Bulletin of Problems of Biology and Medicine, 3, 42-46. [in Ukrainian]. 
Огляди літератури, оригінальні дослідження, погляд на проблему, випадок з практики, короткі повідомлення КЛИНИЧЕСКИЙ ПОРТРЕТ ПАЦИЕНТОВ С ФИБРИЛЛЯЦИЕЙ ПРЕДСЕРДИЙ: ДАННЫЕ СОБСТВЕННЫХ НАБЛЮДЕНИЙ В КОГОРТЕ БОЛЬНЫХ С КОМОРБИДНЫМИ АРТЕРИАЛЬНОЙ ГИПЕРТЕНЗИЕЙ И САХАРНЫМ ДИАБЕТОМ 2-ГО ТИПА

\author{
๑М. В. Гребеник, Ю. В. Гончарук
}

Тернопольский национальный медицинский университет имени И. Я. Горбачевского МОз Украины

РЕЗЮМЕ. Фибрилляция предсердий (ФП) является наиболее распространенным нарушением ритма и регистрируется у 1-2 \% лиц в мире. Предполагается, что к 2060 г. количество лиц с ФП достигнет 17,9 млн. Фремингемское эпидемиологическое исследование показало, что АГ и СД являются независимыми предикторами возникновения ФП. Поэтому предупреждение возникновения, прогнозирование течения данной аритмии у лиц с указанной сопутствующей патологией приобретает особую актуальность.

Цель - провести клинико-функциональное сопоставление развития и течения ФП в условиях коморбидности АГ и СД.

Материал и методы. Обследовано 186 пациентов в возрасте от 20 до 74 лет, в том числе 55,9\% мужчин и $44,1 \%$ женщин. ФП выявлена у 80,1 \% больных (основная группа), не выявлено нарушений ритма у 13,4 \% (контрольная группа).

Результаты. При обследовании больных с ФП выявлено следующее распределение по полу: мужчин 61,7 \%, женщин - 38,3 \%, причем мужчины оказались в среднем на 4 года моложе.

Обнаружено, что такое осложнение гипертонического сердца как ФП чаще всего возникает через 10 лет после обнаружения АГ. Причем при развитии СД ФП возникает быстрее, чем при изолированной АГ. Чем более длительным был анамнез АГ и СД, тем больше больных имели ФП.

Клинически больные с АГ и СД часто не испытывали симптомов рецидива пароксизмов аритмии, что, вероятно, повлияло на прогрессирование патологии.

Оказалось, что длительное употребление алкоголя оказывает непосредственное влияние на изменения показателей ЭхоКГ и, как следствие, возникновение пароксизмов ФП. Сочетание АГ и СД также имеет существенное влияние на ремоделирование сердца и персистенцию ФП. А выраженная ГЛЖ в группе больных с СР и АГ, вероятно, связана с худшим медикаментозным контролем АГ.

Вывод. ФП у больных АГ и СД 2-го типа характеризуется менее яркой клинической симптоматикой, скрытым началом, прогрессированием ремоделирования сердца, склонностью к трансформации в постоянную форму и худшим прогнозом.

КЛЮЧЕВЫЕ СЛОВА: фибрилляция предсердий; артериальная гипертензия; сахарный диабет.

\title{
CLINICAL PORTRAIT OF PATIENTS WITH ATRIAL FIBRILLATION: DATA OF OWN OBSERVATIONS IN A COHORT OF PATIENTS WITH COMORBID ARTERIAL HYPERTENSION AND DIABETES MELLITUS
}

\section{@M. V. Hrebenyk, Yu. V. Honcharuk \\ I. Horbachevsky Ternopil National Medical University}

SUMMARY. Atrial fibrillation (AF) is the most common arrhythmia that affects approximately $1-2 \%$ population. It is assumed that by 2060 the number of people with AF will reach 17.9 million. A Framingham epidemiological study has shown that hypertension and diabetes mellitus are independent predictors of AF. Therefore, prevention and prediction of the course of this arrhythmia, especially in case of comorbidity, becomes even more relevant.

The aim - to conduct clinical and functional comparisons of the development and course of AF in comorbid hypertension and diabetes.

Material and Methods. 186 patients aged 20-74 years were examined. Among them, men - 55.9 \%, women $44.1 \%$. AF was detected in $80.1 \%$ of patients (main group), no arrhythmias were detected in $13.4 \%$ (control group).

Results. Examination of patients with AF revealed the following distribution by sex: men $-61,7 \%$, women $-38,3 \%$. Moreover, men were on average 4 years younger.

It was found that such a complication of hypertensive heart as AF most often occurs 10 years after the detection of hypertension. Moreover, with the development of diabetes AF occurs faster compared to isolated hypertension. The longer the history of hypertension and diabetes, the more patients had AF.

Clinically, patients with hypertension and diabetes often did not experience a recurrence of arrhythmia paroxysms, which probably influenced the progression of the pathology.

It turned out that long-term alcohol consumption has a direct impact on changes in echocardiography and, as a consequence, the occurrence of paroxysms of AF. The combination of hypertension and diabetes mellitus also has a significant effect on cardiac remodeling and AF persistence. And severe left ventricular hypertension in the group of patients with sinus rhythm and hypertension is probably associated with worse drug control of hypertension.

Conclusion. Therefore, AF in patients with hypertension and type 2 diabetes is characterized by less pronounced clinical symptoms, latent onset, progression of heart remodeling, a tendency to transform into a permanent form and a worse prognosis.

KEY WORDS: atrial fibrillation; arterial hypertension; diabetes mellitus.

Отримано 12.04.2021 